\title{
GMR
}

\section{Differential Expression of Dormancy-Associated Genes in Fastigiata and Hypogaea Peanut}

\author{
M.F.C. Silva ${ }^{1}$, C.R.C. Silva ${ }^{2}$, L.M. Lima ${ }^{3}$ and R.C. Santos ${ }^{3}$, Jean Pierre Cordeiro Ramos ${ }^{4}$ \\ ${ }^{1}$ Universidade Estadual da Paraíba, Pós-Graduação em Ciências Agrárias, \\ Campina Grande, PB, Brasil \\ ${ }^{2}$ Renorbio, Universidade Federal Rural de Pernambuco, Recife, PE, Brasil \\ ${ }^{3}$ Empresa Brasileira de Pesquisa Agropecuária, Campina Grande, PB, Brasil \\ ${ }^{4}$ Center of Agrarian Sciences, Federal University of Paraíba, Areia, PB, Brazil \\ Corresponding author: L.M. Lima \\ E-mail: liziane.lima@embrapa.br
}

Genet. Mol. Res. 16 (4): gmr16039820

Received August 30, 2017

Accepted October 25, 2017

Published October 28, 2017

DOI http://dx.doi.org/10.4238/gmr16039820

Copyright (C) 2017 The Authors. This is an open-access article distributed under

the terms of the Creative Commons Attribution ShareAlike (CC BY-SA) 4.0 License.

\begin{abstract}
Seed dormancy is a temporary replacement state observed in some higher plants, which prevents germination under unfavorable conditions. In several species, dormancy process is triggered by hormonal factors, initiated by $\mathrm{ABA}$ and precursor enzymes. In this work, we investigated the relationship between dormancy and the expression of ARP, DMR1, and NCED genes in upright and runner peanut seeds. Eight dormancy-contrasting genotypes were previously phenotyped based on germination traits, during three storage periods. Expression of ARP, DMR1 and NCED transcripts was analyzed by qRT-PCR, from endosperm and embryo tissues. Higher expression of NCED and ARP were found in embryo tissues from runner genotypes, IAC Caiapo and LGoPE-06, confirming findings in literature as to association of these genes with seed dormancy. Higher expression of DMR1 was found only in endosperm of upright materials (L7 Bege and BR1). We suggest the NCED is a functional molecular marker to identify dormancy in
\end{abstract}


seeds, contributing to selection procedures of runner genotypes in peanut breeding.

KEY WORDS: Arachis Hypogaea L, Embryo,

Endosperm, ARP, DMR1 And NCED Genes.

\section{INTRODUCTION}

In agricultural crops, seed dormancy is generally an undesirable characteristic, where rapid germination and growth are required. The level of dormancy in many crops directly affects the quality of yield. Short and shallow dormancy may result in the harmful phenomenon- of pre-harvest sprouting, in which the seeds gain the ability to germinate while they are still on the mother plant (Kermode, 2004). The process triggers in the final stage of maturation of the seed, at the end of the cell cycle and is controlled by several genes and environmental factors, with broad hormonal influence (Hu et al., 2010; Footitt et al., 2014).

Genetic studies have demonstrated that alterations in the ABA biosynthesis can influence seed dormancy and germination. The loss of function of some genes that participate of ABA biosynthetic pathway results in reduced dormancy, whereas higher expression enhances dormancy (Frey et al., 2004; Cadman et al., 2006). Analysis of the expression of genes potentially encoding regulatory enzymes involved in ABA metabolism have been conducted with several crops (Chono et al., 2006; Hwang et al., 2010). Findings reported in literature have demonstrated that NCED (9-cis-epoxycarotenoid dioxygenases), ARP (Auxin Repressor Protein) and DMRI (Dormancy-associated gene 1) are associated with ABA mechanisms, in routes responsible for control of dormancy processes (Footitt et al., 2014). NCED expression in response to environmental stresses is so rapid that NCED activity is considered the rate-limiting step in ABA biosynthesis. Hwang et al. (2010), found higher expression of NCED3 in Arabidopsis, resulting in increased accumulation of $\mathrm{ABA}$ and a delay in germination of transgenic seeds compared to wild-type seeds.

$A R P$ and DRM1 belong to family members that have been involved in response to a number of hormonal and environmental treatments in several plant species. The involvement of $D R M 1 / A R P$ in seed dormancy maintenance has been reported. In Arabidopsis, Schmid et al. (2005) found that high levels of DRMI transcript were reduced with seed imbibition, while transgenic lines higher expressing $D R M 1$ or $A R P 1$ exhibited delayed germination. In a transcriptome study carried out with Brassica oleracea using osmoprimed seeds and water germinated seeds, Soeda et al. (2005) found that DRMI/ARP was expressed only in seeds germinated on water, suggesting that the expression levels of $D R M 1 / A R P$ s throughout germination are not integral to the process but might be indirectly linked. According to these authors, the profile in B. oleracea was shared with several stress-associated genes, including cyclophilin, superoxide dismutase, GRP2, and glutathione-transferase, providing evidence that $D R M 1 / A R P$ may play a more general role in stress response in the seed.

Peanut (Arachis hypogaea L.) is a valuable oilseed crop and known for the differentiated levels of seed dormancy in some genotypes, especially in subspecies hypogaea (Virginia and Runner types) (Faye et al., 2009). In the subspecies fastigiata, represented by upright accesses (Valencia and Spanish types), genotypes are early maturating but generally without fresh seed dormancy. Breeding for fresh seed dormancy in peanut is an important strategy in environments where rains may occur after pod maturity

In several region at worldwide, peanut crop is often carried out in the rainy season, with frequent short summers during the cycle. Environmental changes often interfere with germination and quality of the seeds. The grains contain $45-50 \%$ of oil, which contains $30-35 \%$ polyunsaturated fatty acids and $17-18 \%$ of saturated fatty acids (Santos et al., 2012a; Gunasekaran and Pavadai, 2015). This amount makes peanuts susceptible to oxidative rancidity during processing and storage that is the most common cause of quality loss. Polyunsaturated fatty acids have a high potential of developing off-flavors due to oxidation, which leads to the formation of hydroperoxides. The decomposition of hydroperoxides results in a wide variety of compounds, such as aldehydes and ketones, which interfere on seed germination (Vokou et al., 2003). High linoleic seeds are more resistant to oxidation and are found in Spanish and Valencia genotypes. Although no correlation has been found between fatty acids and germination, it is suggested that rancidity may be involved in the dormancy of hypogaea genotypes, since they have high concentration of oleic acid (Santos et al., 2012a; Gunasekaran and Pavadai, 2015). 
The objective of this work was to investigate the relationship between dormancy and expression of $N C E D, A R P$, and $D M R I$ in seeds of peanut genotypes previously phenotyped, in order to identify markers that could be previously adapted in selection procedures for environments with water restriction.

\section{MATERIAL AND METHODS}

\section{Phenotyping of peanut genotypes}

Eight dormancy-contrasting peanut genotypes were chosen for the trials (Table 1). Five hundred full mature pods were collected from each genotype grown in a field, at Barbalha, CE, Brazil (07'18'40"S; 39 $\left.18^{\prime} 15^{\prime \prime} \mathrm{W}, 414 \mathrm{~m}\right)$ and further stored at room temperature (RT: $23-25^{\circ} \mathrm{C}, 56-66 \%$ relative humidity of air) for a period of up to eight months (240 days). The humidity of the seed at the beginning of storage was between $8-10 \%$. Phenotyping was based on these traits: day to germination, germination rate and seedling height, estimated from seeds of each genotype in three storage periods, at 30 (T0), 150 (T1) and 240 (T2) days. Additionally, the oil content was also evaluated. Seeds were previously treated with Vitavax-Thiram 200SC (5,6-dihydro-2-methyl-1,4-oxathi-ine-3carboxanilide), following manufacturing's recommendation.

\begin{tabular}{|c|c|c|c|c|c|c|c|c|}
\hline Genotype & Subsp. & BT & GH & Genealogy/Origin & SS & DS & Cycle & $100 \mathrm{~S}$ \\
\hline BR 1 & $\mathrm{~F}$ & $\mathrm{~V}$ & $\mathrm{U}$ & Cv. $(\mathrm{V}) / \mathrm{PB}, \mathrm{BR}$ & $\mathrm{M}$ & No & 89 & 45 \\
\hline BRS Havana & $\mathrm{F}$ & $\mathrm{V}$ & $\mathrm{U}$ & Cv. (V)/PB, BR & $\mathrm{M}$ & No & 90 & 46 \\
\hline L7 bege & $\mathrm{F}$ & $\mathrm{V}$ & $\mathrm{U}$ & Top line $(\mathrm{V} \mathrm{X} \mathrm{S}) / \mathrm{PB}, \mathrm{BR}$ & $\mathrm{L}$ & No & 90 & 49 \\
\hline IAC Caiapo & $\mathrm{H}$ & $\mathrm{Vi}$ & $\mathrm{R}$ & Cv. $(\mathrm{Vi}$ X S)/SP, BR & $\mathrm{L}$ & Yes & 135 & 52 \\
\hline Cavalo & $\mathrm{H}$ & $\mathrm{Vi}$ & $\mathrm{R}$ & Land race/RO, BR & EL & Yes & 145 & 68 \\
\hline LViPE-07 & $\mathrm{H}$ & $\mathrm{Vi}$ & $\mathrm{R}$ & Land race/PE, BR & EL & Yes & 152 & 72 \\
\hline LGoPE-06 & $\mathrm{H}$ & $\mathrm{Vi}$ & $\mathrm{R}$ & Land race/PE, BR & EL & Yes & 153 & 70 \\
\hline Florunner & $\mathrm{H}$ & $\mathrm{Vi}$ & $\mathrm{R}$ & Cv. (Vi)/USA & $\mathrm{L}$ & Yes & 138 & 51 \\
\hline
\end{tabular}

Subsp. F- fastigiata, H- hypogaea; BT- botanic type, V- Valencia, Vi- Virginia; GH- growth habit, U- upright, R- runner; Cv.commercial cultivar; SS- seed size, M- mid, L- large, EG- extra-large; DS- dormancy in seed; 100S- 100 seed weight (g).

The germination analysis was carried out in BOD (Biochemical Oxygen Demand- growth chamber) chamber, using paper towel method (Abdul Baki and Anderson, 1973). Seeds were sown in rolled paper towels (Germitest) moistened with $10 \mathrm{~mL}$ of distilled water, and incubates at $25^{\circ} \mathrm{C}$. After seven days of incubated, the number of seeds that had germinated was counted and measured the length of seedlings. The experiment was repeated three times with two replicates of fifty seeds each. The rate of germination was estimated by: $\% \mathrm{G}=\mathrm{NSG} / \mathrm{NST} \times 100$ ( $\% \mathrm{G}=$ Total Germination; NSG $=\mathrm{N}$ of germinated seeds; NST $=\mathrm{N}$ of tested seeds).

The oil content was estimated by Nuclear Magnetic Resonance spectrometer (H1 OXFORD MQA 7005), following recommendation described in AOCS (2004). The test was repeated three times with two replicates of twenty seeds each. Samples were collected by chance to each repetition.

Data were subjected to analysis of variance (ANOVA), using GENES software (Cruz, 2013). Significant effects of treatments were determined by F test $(\mathrm{p} \leq 0.05)$. Means were separated using Tukey’s test $(\mathrm{p} \leq 0.05)$.

\section{Expression analysis via RT-qPCR}

Embryo and endosperm tissues were used for extraction of total RNA (Invisorb Spin Plant Mini Kit, Invitek, Germany) and further synthesis of cDNA (ImProm-II ${ }^{\mathrm{TM}}$ Reverse Transcription System kit, Promega), following manufacturer's recommendations. The reverse transcription was performed in $44 \mu \mathrm{L}$, using $11 \mu \mathrm{L}$ of cDNA sample (1 $\mu \mathrm{g}$ total RNA), $0.5 \mu \mathrm{g}$ Oligo dT 15 (10 mM), 1 X ImProm-II Reaction Buffer, $6 \mu \mathrm{L} \mathrm{MgCl}_{2}(25 \mathrm{mM}), 0.5$ $\mu \mathrm{L}$ dNTP set $(10 \mathrm{mM}), 1 \mathrm{U} / \mu \mathrm{L}$ Recombinant RNase Ribonuclease Inhibitor; $1.25 \mathrm{U} / \mu \mathrm{L}$ ImProm-II ${ }^{\mathrm{TM}} \mathrm{RT}$. Samples were incubated in a thermal cycler, first at $25^{\circ} \mathrm{C} / 5 \mathrm{~min}$, then at $42^{\circ} \mathrm{C} / 1 \mathrm{~h}$ and $70^{\circ} \mathrm{C} / 15 \mathrm{~min}$.

The relative expression of $N C E D, A R P$ and $D M R l$ transcripts was estimated by qRT-PCR (Eco Real-Time PCR System - Illumina, SD, USA) using Evagreen kit (Biotium Inc., Hayward, CA, USA), according to manufacturer's instructions. The primers used in this study were previously designed from conserved regions of NCED (gi 340764664, Glycine max, gi 6715256, Phaseolus vulgaris, gi 22335698, Pisum sativum, gi 4276042, Arachis hypogaea, ARP (gi71040686, A. thaliana, gi 357446688, Medicago truncatula) and DMRl (gi 2995989, A. thaliana, gi 2605886, Pisum sativum, gi 229893931, Brassica rapa) from several accessions available in NCBI 
gene bank. The ClustalW2 program (www.ebi.ac.uk) was used to alignment of sequences. The set of primers used in assays are displayed in Table 2.

Table 2. Sequence of specific and constitutive primers used in assays.

\begin{tabular}{cc}
\hline Gene & Primers (Forward/Reverse, $\mathbf{5}^{\prime} \rightarrow \mathbf{3}^{\prime}$ ) \\
\hline $\boldsymbol{N C E D}$ & GAAGGAAGACACAGTTCGCA/ \\
& AGGAAGAAACATCGGCTCAC \\
\hline $\boldsymbol{A R P}$ & GGTTCTGTTAGAGAAGCTG/ \\
& GCGGTGCTTGCTCCTTGTC \\
\hline $\boldsymbol{D M R \boldsymbol { I }}$ & GGATGATATTGTTGCTGGCC/ \\
& CGCAATCGACGTGCTTCTCA \\
\hline $\boldsymbol{\beta}$-atina & GATCTGGCATCACACCTTC/ \\
& AGGAAGCTCGTAGCAGCTCTT \\
\hline $\boldsymbol{P P 2} \boldsymbol{A}^{* *}$ & GTCATCCTTTCAGGTACAAGCA/ \\
& CGTTACAAACAACAGCTCCTTC \\
\hline
\end{tabular}

*Batista et al. (2015); **Ártico et al. (2014); PP2A- Protein phosphatase 2A.

Primers were used at $10 \mathrm{mM}$ and designed to amplify at $60^{\circ} \mathrm{C}$. All reactions were carried out with experimental triplicate and biological duplicate. The threshold cycle $(\mathrm{Ct})$ and PCR efficiency was estimated by Real-time PCR Miner program (Zhao and Fernald, 2005). The analyses of gene expression were performed using the qBASEPlus program (Hellemans et al., 2007). The graphics, Cqs and Melt curves were automatically generated based on the normalization method with a reference gene, $\Delta \Delta \mathrm{Cq}$ (Livak et al., 2001). Relative quantification estimated the expression pattern.

\section{RESULTS AND DISCUSSION}

\section{Phenotyping of fastigiata and hypogaea genotypes}

The traits used to phenotyping fastigiata (upright) and hypogaea (runner) genotypes were adequate to identify contrasting materials to seed dormancy. No evidence of dormancy was found in upright genotypes, based on data provided in Figure 1. The profile of BR 1 and BRS Havana was quite similar (Figure 1). 

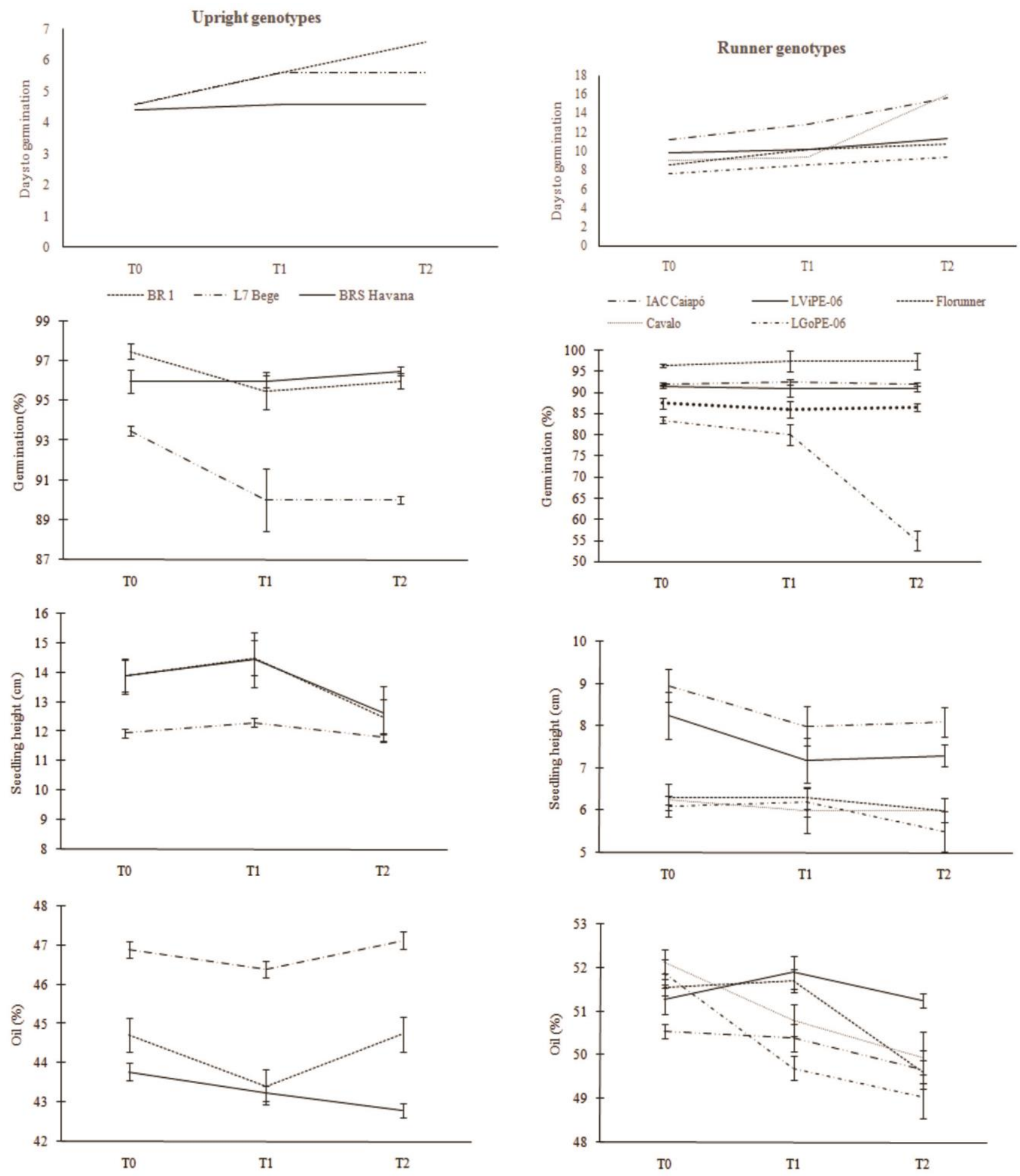

Figure 1. Days to germination, germination rate, seedling height and oil content from seeds of upright and runner genotypes of peanut. T0, T1 and T2 mean the periods that seeds were collected to assays, at 30,150 and 240 days after the beginning of pod storage at RT.

No expressive lapse was found to germination of both cultivars. The rate of germination was $96 \%$ during the assay. The height of seedling, however, decreased in $14 \%$ at 240 days of pod storage. In L7 bege, a slight delay on germination was found at final of assay (T2). The rate of germination decreased in 7\%, nevertheless, no statistical difference was seen in height of seedlings during storage period. These slight oscillations are often expected in oil seeds, stored at room temperature (Almeida et al., 2010).

In runner genotypes, the process of germination started at 8 to 12 days in T0 treatment, reaching 17 days in the more dormant genotypes (IAC Caipo and Cavalo), at the end of assays. The rate of germination was maintained 
almost uniform to all materials, between $87 \%$ to $98 \%$, excepting to Cavalo that started at $85 \%$ (T0) and reached $55 \%$, at 210 days of pod storage (T2). No statistical difference was found to Florunner, LViPE-06 and Cavalo to seedling height in all treatments, while in IAC Caiapo and LGoPE-06, the height was reduced to $11 \%$ and $12 \%$, respectively, from 150 days (T1) of pod storage at RT.

The variation of oil content was not expressive in both set of genotypes. No statistical differences were found to upright genotypes, but in runner types, reductions were situated among 4\% (LViPE-06 and Florunner) and 6\% (Cavalo). IAC Caiapó and LGoPE-06 did not show statistical differences during the periods of storage evaluated.

Literature displays several reports involving germination of oleaginous seeds under large storage period (Neergaard, 1977; Bhattacharya and Raha, 2002; Balešević-Tubić et al., 2010). According to Neergaard (1977) seeds with high oil content possess lower moisture than those with high protein or starch. In peanut, no evident correlation has been found in dormancy and storage, but rancidity is involved with oleic/linoleic ratio, which is higher in runner genotypes (Bhattacharya and Raha, 2002; Balešević-Tubić et al., 2010; Santos et al., 2012a). High rancidity interferes on seed germination of peanut seeds (Santos et al., 2012a; Gunasekaran and Pavadai, 2015). Some peanut researchers have used intersubpecies crosses in order to minimize the effect of rancidity and maintain the dormancy of the seeds (Wadia et al., 1987; Faye et al., 2009; Santos et al., 2012a). According to Wadia et al. (1987), Virginia x Spanish crosses may lead to lines with fresh seed dormancy but matures up to 10 days latter than the Spanish parent. Faye et al. (2009) report the existence of dormancy in the fastigiata types, although to a lesser extent. In an evaluation of dormancy on lines derived from crosses between Spanish genotypes, authors found intensity of dormancy ranging from $12 \%$ to $100 \%$, with duration varying from 15 to 35 days.

Based on these information, we choose LGoPE-06, and IAC Caiapo representing moderate and deep dormant treatments, respectively, for further molecular assays. LGoPE-06 is a decumbent runner used in Brazilian peanut breeding coordinated by Embrapa (Brazilian Agricultural Research Corporation) due its high pod yield and extralarge seed (Santos et al., 2012a). IAC Caiapo is a cultivar generated by Spanish x Virginia cross and widely cropped by peanut farmers situated at Brazilian southeast. The upright genotypes BR 1 and L7 bege, were chosen to represent no-dormant treatment.

\section{Relative expression of $N C E D, A R P$, and $D M R$}

ABA represses germination and is presumed to function to stabilize the dormant state in seeds (Kermode, 2005; Finkelstein et al., 2008). ABA deficiencies during seed development are associated with the absence of primary dormancy of mature seed, whereas higher expression of ABA synthesis genes increases the ABA content and seed dormancy or delay germination (Qin and Zeevaart, 2002; Finkelstein et al., 2008). Several genes are associated with ABA regulation, including $N C E D$, whose role in seed dormancy is widely described in the literature. According to Kermode (2005), the expression of the NCED is upregulated in embryos during imbibition of both dormant and non-dormant seeds; however, it is induced to a greater extent in embryos of dormant imbibed grains. In seeds of Arabidopsis, tomato and tobacco, the whereas higher expression of ABA synthesis genes increases the ABA content of NCED leads to higher ABA level, increasing seed dormancy (Luchi et al., 2001; Qin and Zeevaart, 2002).

Here, we also found higher expression of NCED in dormant seeds of peanut genotypes. As show in figure 2A, transcripts were basically found in embryo tissues of runner genotypes, with higher expression in deep-dormant IAC Caiapo (50x). These results attest that NCED can be adopted as a marker of dormancy in embryos of peanut seeds, confirming results found in the literature.

The biosynthetic network of genes involved in dormancy process is large and complex. NCEDs and CYP707As (ABA 8'-hydroxylases) are the major key regulatory enzymes for ABA biosynthesis and degradation, respectively. Both are encoded by multigene families, and their tissue- and environment-specific regulation determines the ABA contents (Qin and Zeevaart, 2002; Ali-Rachedi et al., 2004; Finkelstein et al., 2008). In works carried out with deep dormant seeds of Arabidopsis, Ali-Rachedi et al. (2004) have demonstrated that dormancy may depend on an intrinsic balance of GA (Gibberellic acid) and ABA biosynthesis and catabolism, which will determine the dominance of either of the hormones. According to the authors, GA treatment of dormant seeds caused a transient increase in ABA concentration, suggesting that in dormant seeds a feedback mechanism exists that maintains a high $\mathrm{ABA}$ :GA ratio. 
It is believed that in many cases the interactions between ABA and other hormones result in a process in which dormancy and gem growth are regulated by the balance between gem growth inhibitors such as ABA and promoter substances such as cytokinins, gibberellins, and auxins. Although ABA and gibberellins are known to be the primary phytohormones that antagonistically regulate seed dormancy, recent findings demonstrate that another phytohormone, auxin, is also critical for inducing and maintaining seed dormancy, and therefore might act as a key protector of seed dormancy (Shu et al., 2015).
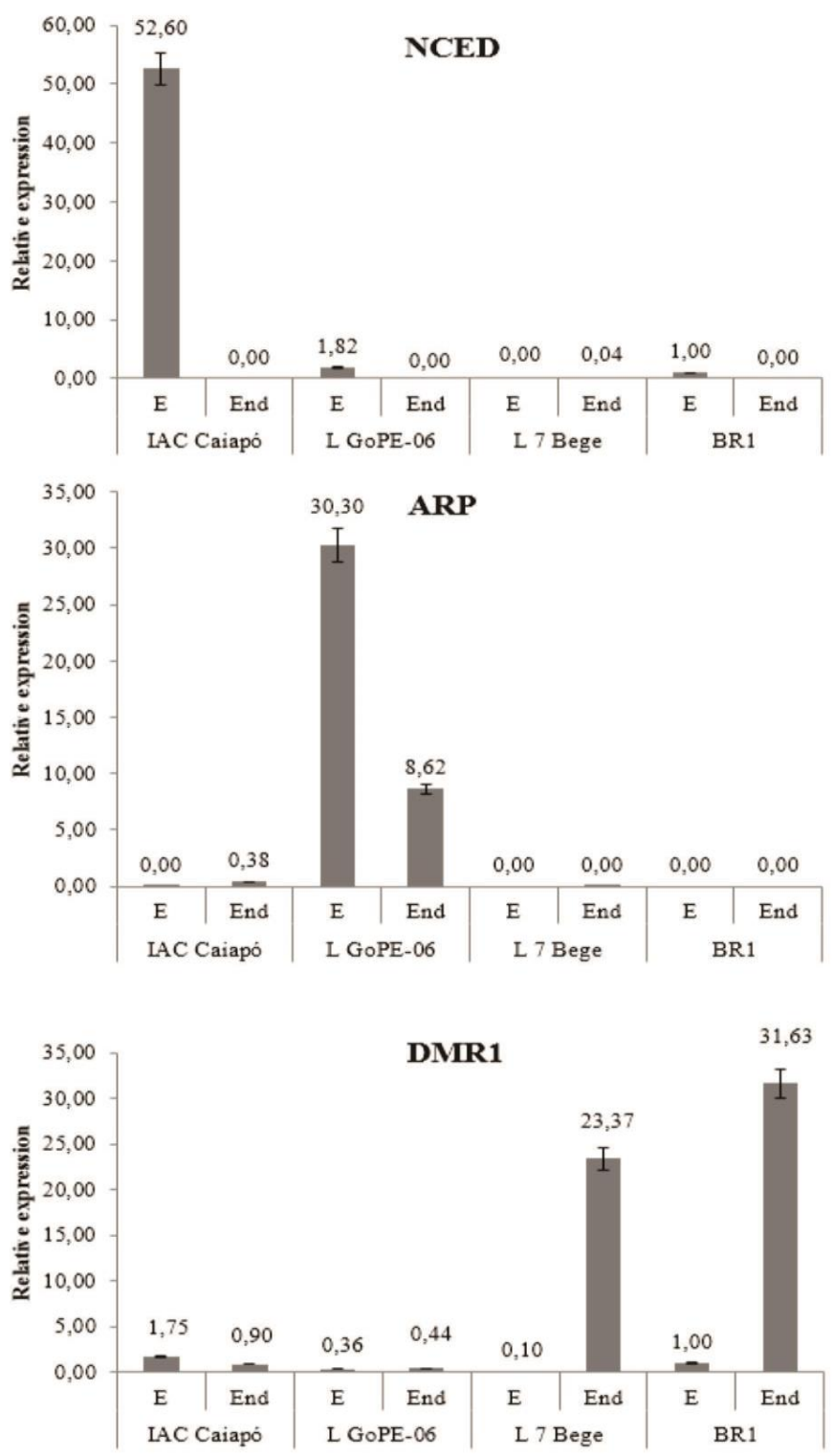

Figure 2. Relative expression of $N C E D, A R P$ and $D M R 1$ genes in embryo (E) and endosperm (End) tissues of runner and upright peanut genotypes. The error bars indicate standard deviation of mean.

Auxin, a common growth-stimulating phytohormone, regulates a variety of growth and developmental processes in plants, leading to changes in the expression of many auxin-activated and auxin-repressed genes. ARP and $D R M$ genes are closely related and isolated from dicots and monocots. Both form the ARP/DRM gene family and are often used as a genetic marker for dormant meristematic and seed tissues (Lee et al., 2013; Rae et al., 2013). In a study of molecular characterization of the Brassica rapa auxin-repressed superfamily genes, Lee et al. (2013) found that increases in both BrARP1 and BrDRM1 levels in Arabidopsis plants caused delayed germination; reduction in root, hypocotyl, and leaf growth; and reduction in final plant size and seed production.

Here, the expression of $A R P$ in peanut genotypes is shown in figure $2 \mathrm{~B}$. Transcription was found only in runner genotypes, higher expression in endosperm (8x) and embryo of LGoPE-06 (up to 30x). Seeds of LGoPE-06 are 
extra-large, rich in fatty acids and more tolerant to drought than IAC Caiapo (Santos et al., 2012a and b). Findings in the literature report transcriptional upregulation of $D R M 1 / A R P$ family members in response to abiotic factors, such as drought and salt, in several species including A. hypogaea (Shimizu et al., 2006; Govind et al., 2009). Considering that both runner genotypes have expressive seed dormancy, it is possible that higher expression found in LGoPE-06 could be associated with expression of other traits, such as environmental adaptation. While IAC Caiapo was developed to environments with regular rainfall, LGoPE-06 is a top line improved to the semiarid region of Brazilian Northeast (Santos et al., 2012b).

As to DMRl transcripts shown in Figure 2C, the pattern of expression obtained to IAC Caiapo was similar to that seen for $A R P$ (Figure 2B), in both tissues. Low expression was found in other genotypes, except for a higher expression in the endosperm of upright materials. As most of the results found in the literature with NCED, ARP, and $D M R l$ have been reported in dormant seeds, we have done a vast search in order to explain the expression profile seen in upright genotypes. According to Rae et al. (2013), besides the processes of dormancy, regulation of $D R M 1 / A R P$ has been assessed in response to a number of treatments: hormonal, sugars, and abiotic and biotic across a number of plant species. In peanut, Govind et al. (2009) reported DRMI/ARP transcript expression in response to gradual water stress. As BR 1 and L7 bege are earliness and widely tolerant to drought (Duarte et al., 2013), we suggest that higher expression found in endosperm of these materials could be benefited by effect of this trait.

In this work, we estimated the expression of NCED, ARP and DMRl in previously phenotyped dormant-seed peanut germplasm. Although the results obtained here have been quite interesting in the aspect of expression in the different tissues, we suggest that $N C E D$ is more suitable for further use in selection procedures, in breeding works for runner peanut improvement.

\section{CONFLICT OF INTERESTS}

The authors declare no conflict of interest in the conduction of this study.

\section{ACKNOWLEDGMENTS}

The authors thank Embrapa and CAPES for financial support and scholarship, respectively.

\section{REFERENCES}

Artico S, Lambret-Frotté J, Nardeli SM, Oliveira-Neto OB, et al. (2014). Isolation and characterization of three new promoters from Gossypium hirsutum that show high activity in reproductive tissues. Plant Mol. Biol. Rep. 32: 630-643. https://doi.org/10.1007/s11105-0130674-0

Abdul Baki AA, Anderson JD (1973). Vigor determination in soybean seed by multiple criteria. Crop Sci. 13: 630-633.

https://doi.org/10.2135/cropsci1973.0011183x001300060013x

Ali-Rachedi S, Bouinot D, Wagner MH, Bonnet M, et al. (2004). Changes in endogenous abscisic acid levels during dormancy release and maintenance of mature seeds: studies with the Cape Verde Islands ecotype, the dormant model of Arabidopsis thaliana. Planta. 219: 479-488. https://doi.org/10.1007/s00425-004-1251-4

Almeida FAC, Jerônimo ES, Alves NMC, Gomes JP, et al. (2010). Estudo de técnicas para o armazenamento de cinco oleaginosas em condições ambientais e criogênicas. Rev. Bras. Prod. Agro. 12: 189-202. https://doi.org/10.15871/1517-8595/rbpa.v12n2p189-202

AOCS (2004). American Oil Chemists Society. Official Methods and recommended practices of the aoac, sampling and analysis of vegetable oil source materials, Section A. AOCS recommended practice Ak 5-01 approved 2001. Simultaneous determination of oil and moisture contents of oilseed residues using pulsed nuclear magnetic resonance spectrometry. In: American Oil Chemists Society. Official methods and recommended practices of the AOCS. 5 ed., AOCS, Champaign, Ill. 4

Batista VGL, Pinheiro MPN, Melo Filho PA, Santos RC, et al. (2015). Temporal and tissue expression of genes involved in buds of earliness cotton cultivar. Gen. Mol. Res. 3: 7386-7394. https://doi.org/10.4238/2015.july.3.14

Balešević-Tubić S, Tatić M, Đorđević V, Nikolić Z, et al. (2010). Seed viability of oil crops depending on storage conditions. Helia. 52: 153160. https://doi.org/10.2298/hel1052153b

Bhattacharya K, Raha S (2002). Deteriorative changes of maize, groundnut, and soybean seeds by fungi in storage. Mycopathologia. 155: $135-141$.

Cadman CSC, Toorop PE, Hilhorst HWM, Finch-Savage WE (2006). Gene expression profiles of Arabidopsis Cvi seeds during dormancy cycling indicate a common underlying dormancy control mechanism. Plant J. 46: 805-822.https://doi.org/10.1111/j.1365-313x.2006.02738.x 
Chono M, Honda I, Shinoda S, Kushiro T, et al. (2006). Field studies on the regulation of abscisic acid content and germinability during grain development of barley: molecular and chemical analysis of pre-harvest sprouting. J. Exp. Bot. 57: 2421-2434. https://doi.org/10.1093/jxb/erj215

Cruz CD (2013). GENES - a software package for analysis in experimental statistics and quantitative genetics. Acta Sci. Agron. 35: 271-276. https://doi.org/10.4025/actasciagron.v35i3.21251

Duarte EAA, Melo Filho PA and Santos RC (2013). Características agronômicas e índice de colheita de diferentes genótipos de amendoim submetidos a estresse hídrico. Rev. Bras. Eng. Agríc. Ambient. 17: 843-847. https://doi.org/10.1590/s1415-43662013000800007

Faye I, Ndoye O, Diop TA (2009). Evaluation of fresh seed dormancy on seven peanut (Arachis hypogeae L.) lines derived from cross between Spanish varieties: Variability on intensity and duration. J. Appl. Sci. Res. 5: 853-857.

Finkelstein RR, Reevers W, Ariizumi T, Steber C (2008). Molecular aspects of seed dormancy. Ann. Rev. Plant Biol. 59: 387-415.

Footitt S, Clay HA, Dent K, Finch-Savage WE (2014). Environment sensing in spring-dispersed seeds of a winter anual Arabidopsis influences the regulation of dormancy to align germination potential with seasonal changes. New Phytol. 202: 929-939. https://doi.org/10.1111/nph.12694

Frey A, Godin B, Bonnet M, Sotta B, et al. (2004). Maternal synthesis of abscisic acid controls seeds development and yield in Nicotiana plumbaginifolia. Planta 218: 958-964. https://doi.org/10.1007/s00425-003-1180-7

Govind G, Harshavardhan VT, Patricia JK, Dhanalakshmi R, et al. (2009). Identification and functional validation of a unique set of droughts induced genes preferentially expressed in response to gradual water stress in peanut. Mol. Genet. Genomics. 281: 591-605. https://doi.org/10.1007/s00438-009-0441-y

Gunasekaran A, Pavadai P (2015). Studies on induced physical and chemical mutagenesis in groundnut (Arachis hypogaea). Int. Lett. Nat. Sci. 8: 25-35.https://doi.org/10.18052/www.scipress.com/ilns.35.25

Hellemans J, Mortier G, De Paepe A, Speleman F, et al. (2007). qBase relative quantification framework and software for management and automated analysis of real-time quantitative PCR data. Genome Biol. 8: R19.

Hu B, Wan X, Liu X, Guo D, et al. (2010) Abscisic acid (ABA)-mediated inhibition of seed germination involves a positive feedback regulation of ABA biosynthesis in Arachis hypogaea L. Afr. J. Biotechnol. 9: 1578-1586. https://doi.org/10.5897/ajb10.1819

Hwang SG, Chen HC, Huang WY, Chu YC, et al. (2010) Ectopic expression of rice OsNCED3 in Arabidopsis increases ABA level and alters leaf morphology. Plant Sci. 178: 12-22. https://doi.org/10.1016/j.plantsci.2009.09.014

Kermode AR (2004) Developmental traits. Germination. In: Handbook of plant biotechnology (Klee H, Christou P, eds.). UK: John Wiley \& Sons.

Kermode AR (2005). Role of abscisic acid in seed dormancy. J. Plant Growth Regul. 24: 319-344. https://doi.org/10.1007/s00344-005-01102

Lee J, Han CT, Hur Y (2013). Molecular characterization of the Brassica rapa auxin-repressed, superfamily genes, BrARP1 and BrDRM. Mol. Biol. Rep. 40: 197-209. https://doi.org/10.1007/s11033-012-2050-9

Livak KJ, Schmittgen TD (2001) Analysis of relative gene expression data using real-time quantitative PCR and the 2(-Delta Delta C(T)) method. Methods. 25: 402-408. https://doi.org/10.1006/meth.2001.1262

Luchi S, Kobayashi M, Taji T, Naramoto M, et al. (2001). Regulation of drought tolerance by gene manipulation of 9-cis-epoxycarotenoid dioxygenase, a key enzyme in abscisic acid biosynthesis in Arabidopsis. Plant J. 27: 325-333. https://doi.org/10.1046/j.1365$\underline{313 x .2001 .01096 . x}$

Neergaard P. (1977) Seed pathology. MacMillan Press, London.

Qin X, Zeevaart JA (2001). Overexpression of a 9-cis-epoxycarotenoid dioxygenase gene in Nicotiana plumbaginifolia increases abscisic acid and phaseic acid levels and enhances drought tolerance. Plant Physiol. 128: 544-551. https://doi.org/10.1104/pp.010663

Rae GM, David KM and Wood M (2013). The dormancy marker DRM1/ARP: associated with dormancy but a broader role in planta. Dev. Biol. J. ID 632524: 12 pages. http://dx.doi.org/10.1155/2013/632524

Santos RC, Freire RMM, Lima LM, Zagonel GF, et al. (2012). Produtividade de grãos e óleo de genótipos de amendoim para o mercado oleoquímico. Rev. Ciên. Agron. 43: 72-77. https://doi.org/10.1590/s1806-66902012000100009

Santos RC, Silva AF, Gondim TMS, Oliveira-Júnior JOL, et al. (2012b). Stability and adaptability of runner peanut genotypes based on nonlinear regression and AMMI analysis. Pesq. Agropec. Bras. 47: 1118-1124. https://doi.org/10.1590/s0100-204x2012000800012

Schmid M, Davison TS, Henz SR, Pape UJ, et al. (2005). A gene expression map of Arabidopsis thaliana development. Nat. Genet. 37: 501506 .

Shimizu M, Suzuki K, Miyazawa Y, Fujii N, et al. (2006). Differential accumulation of the mRNA of the auxin-repressed gene CsGRP1 and the auxin-induced peg formation during gravimorphogenesis of cucumber seedlings. Planta 225: 13-22. https://doi.org/10.1007/s00425-006$\underline{0324-y}$

Shu K, Liu XD, Xie Q, He ZH (2015). Two faces of one seed: hormonal regulation of dormancy and germination. Mol. Plant 5: 1674-2052. 
https://doi.org/10.1016/j.molp.2015.08.010

Soeda Y, Konings MCJM, Vorst O, van Houwelingen AMML, et al. (2005). Gene expression programs during Brassica oleracea seed maturation, osmopriming, and germination are indicators of progression of the germination process and the stress tolerance level. Plant Physiology, 137: 354-368. https://doi.org/10.1104/pp.104.051664

Vokou D, Douvli P, Blionis GP, Halley JM. (2003). Effects of monoterpenoids, acting alone or in pairs, on seed germination and subsequent seedling growth. J. Chem. Ecol. 29: 2281-2301.

Wadia KDR, Nageswara Rao RC and William JH (1987). An improved method for identification of dormant sequentially branched progenies from populations derived from crosses between non-dormant (subspecies fastigiata) and dormant (subspecies hypogaea) groundnut (Arachis hypogaea L.). Oléagineux 42: 75-82.

Zhao S and Fernald RD (2005). Comprehensive algorithm for quantitative real-time polymerase chain reaction. J. Comput. Biol. 12: 10451062. https://doi.org/10.1089/cmb.2005.12.1047 